\title{
Interannual variations of the terrestrial water storage in the Lower Ob' Basin from a multisatellite approach
}

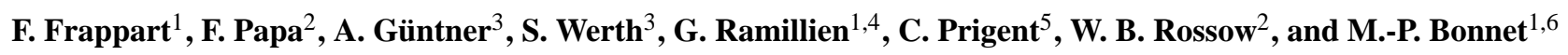 \\ ${ }^{1}$ Université de Toulouse, OMP, GET, UMR 5563, Toulouse, France \\ ${ }^{2}$ NOAA Cooperative Remote Sensing Science and Technology Center, City College of New York, New York, USA \\ ${ }^{3}$ GFZ, Telegrafenberg, Potsdam, Germany \\ ${ }^{4}$ CNRS, OMP, GET, UMR 5563, Toulouse, France \\ ${ }^{5}$ Laboratoire d'Etudes du Rayonnement et de la Matière en Astrophysique, Observatoire de Paris, CNRS, Paris, France \\ ${ }^{6}$ IRD,OMP, GET, UR 154, Toulouse, France
}

Received: 23 July 2010 - Published in Hydrol. Earth Syst. Sci. Discuss.: 1 September 2010

Revised: 24 November 2010 - Accepted: 1 December 2010 - Published: 6 December 2010

\begin{abstract}
Temporal variations of surface water volume over inundated areas of the Lower Ob' Basin in Siberia, one of the largest contributor of freshwater to the Arctic Ocean, are estimated using combined observations from a multisatellite inundation dataset and water levels over rivers and floodplains derived from the TOPEX/POSEIDON (T/P) radar altimetry. We computed time-series of monthly maps of surface water volume over the common period of available T/P and multisatellite data (1993-2004). The results exhibit interannual variabilities similar to precipitation estimates and river discharge observations. This study also presents monthly estimates of groundwater and permafrost mass anomalies during 2003-2004 based on a synergistic analysis of multisatellite observations and hydrological models. Water stored in the soil is isolated from the total water storage measured by GRACE when removing the contributions of both the surface reservoir, derived from satellite imagery and radar altimetry, and the snow estimated by inversion of GRACE measurements. The time variations of groundwater and permafrost are then obtained when removing the water content of the root zone reservoir simulated by hydrological models.
\end{abstract}

\section{Introduction}

All climate scenarios agree on the high sensitivity of the northern regions to global change, with a stronger warming at these latitudes than globally. Average annual Arctic

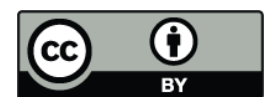

Correspondence to: F. Frappart (frederic.frappart@lmtg.obs-mip.fr) temperatures have increased at almost twice the global rate over recent decades and are predicted to increase by an additional $4-7^{\circ} \mathrm{C}$ by the end of the 20th century (Serreze et al., 2000). Continued warming of the Arctic regions will likely have profound consequences, many of which may have regional and global implications (Peterson et al., 2002). For instance, an increase in air temperature is expected to intensify the Arctic hydrological cycle (Stocker and Raible, 2005; Wu et al., 2005) and important modifications of the terrestrial water cycle have been already observed in these northern latitudes. One observable change that attracted considerable scientific attention is the increase over the last century by $7 \%$ in the average annual discharge of fresh water from the six largest Eurasian rivers to the Arctic Ocean (Peterson et al., 2002; Yang et al., 2002). Other recent evidences of change in the Arctic hydrology were revealed with the analysis of optical remote sensing images by Smith et al. (2005) which showed a reduction between 1975 and 1997 in the number of lakes in West Siberia that could be related to permafrost thawing. These modifications could lead to significant repercussions on both the biogeochemical and hydrological cycles of northern high latitude systems, with further influence on the global climate.

Among the various reservoirs in which fresh water on land is stored (e.g., ice caps, glaciers, snowpack, soil moisture and groundwater), surface waters (rivers, lakes, reservoirs, wetlands and inundated areas) play a crucial role in the global biogeochemical and the hydrological cycles (de Marsily et al., 2005). Although wetlands and floodplains cover only $6 \%$ of the Earth surface (OECD, 1996), they have a substantial impact on flood flow alteration, sediment stabilization, water quality, groundwater recharge and discharge (Maltby, 1991;

Published by Copernicus Publications on behalf of the European Geosciences Union. 
Bullock and Acreman, 2003). Moreover, floodplain inundation is an important regulator of river hydrology owing to storage effects along channel reaches. Reliable and timely information about the extent, spatial distribution, and temporal variation of wetlands and floods as well as the amount of water stored is crucial to better understand their relationship with river discharges, and also their influence on regional hydrology and climate.

Remote sensing techniques have been very useful for studying cold region climate and hydrology (Massom, 1995; Smith, 1997; Seidel and Martinec, 2004) as they provide a unique mean to observe large regions. Good capabilities for monitoring snow extent and depth using passive microwave measurements (Yang et al., 2002; Grippa et al., 2005) or multispectral images (Hall et al., 2002; Robinson and Frei, 2000), water levels and discharges using radar altimetry (Kouraev et al., 2005), and inundation extent combining multisatellite information (Papa et al., 2007, 2008a) have already been demonstrated. The Gravity Recovery And Climate Experiment (GRACE) mission, launched in 2002, detects tiny changes in the Earth's gravity field which can be related to the spatio-temporal variations of the terrestrial water storage (TWS) at monthly or 10-day time-scales (Tapley et al., 2004). Previous studies provide important information on changes in TWS and snow mass at high latitudes (Muskett and Romanovsky, 2009; Frappart et al., 2010). TWS, representing an integrated measurement of the water stored in the different hydrological reservoirs, and consequently, the sum of the surface water, water stored in the root zone, snowpack and groundwater, can be considered as a good indicator of the changes that occur in the hydrological conditions globally, and at basin-scale. Nevertheless, TWS is difficult to measure due to the lack of a complete network of in situ observations of the terrestrial hydrological components. The hydrologic regime of rivers is strongly influenced by the presence of permafrost at high latitudes. The river basins with high permafrost coverage have lower subsurface storage capacity, which causes a lower winter baseflow and a higher summer peak flow, than basins with low coverage (Woo, 1986; Kane, 1997; Smith et al., 2007).

Variations in the groundwater storage can be extracted from the TWS measured by GRACE using external information on the other hydrological reservoirs such as in situ observations (Yeh et al., 2006), model outputs (Rodell et al., 2009), or both (Leblanc et al., 2009). No similar studies have been yet undertaken for large river basins characterized by extensive wetlands or floodplains in high latitude regions.

In this study, we demonstrate that remote sensing and hydrological modelling can be combined to estimate water storage changes in the Lower Ob' Basin by combining highresolution imagery-derived inundation extents, altimetryderived water level measurements and gravimetry from space products, and soil water outputs from hydrological models. We first present the analysis of twelve years of surface water storage variations. Then, water storage anomalies of surface

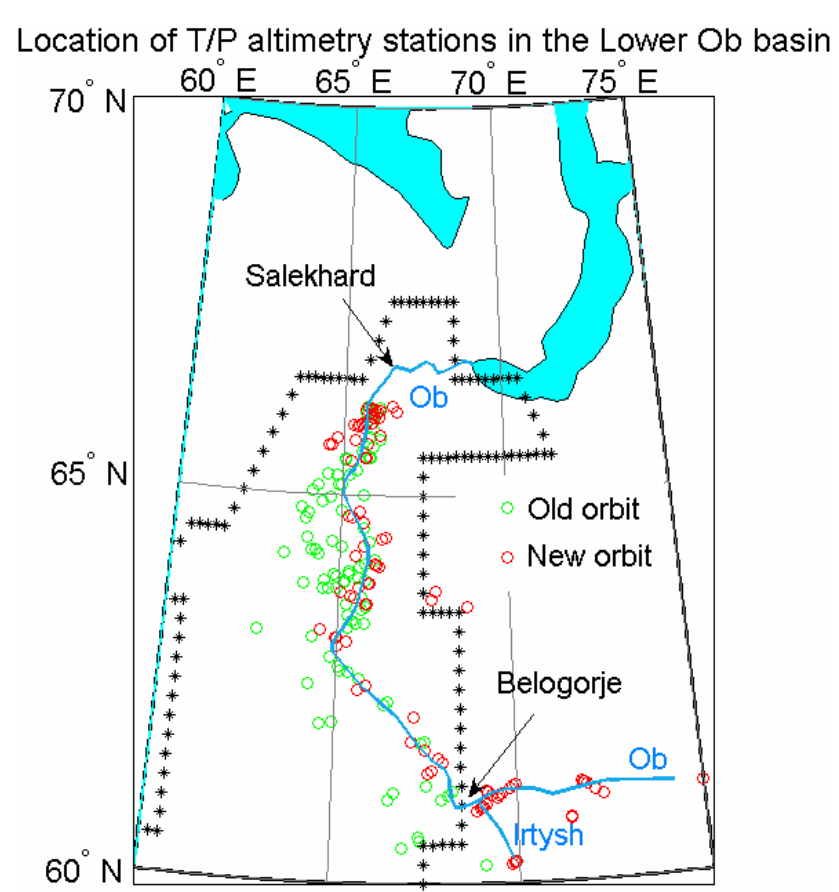

Fig. 1. Map of Lower Ob' Basin and locations of the Topex/Poseidon water level stations. The line with stars shows the delineation of the watershed.

waters and snow reservoir are removed from the TWS measured by GRACE to isolate the total soil storage (i.e., the sum of the soil, groundwater and permafrost storages) over 2003-2004 in the Lower Ob' basin.

\section{Study area and datasets}

\subsection{The Lower Ob’ Basin}

The $\mathrm{Ob}^{\prime}$ is the largest watershed of all Arctic rivers $\left(2975106 \mathrm{~km}^{2}\right)$ and is the third largest contributors of freshwater to the Arctic ocean after the Yenisey and Lena rivers (Shiklomanov et al., 2000). This watershed is mostly underlain by discontinuous permafrost with portions of continuous permafrost in its northern part and sporadic permafrost in its southern part (Brown et al., 1998; Zhang et al., 1999) and during the winter, a large part of the basin is covered by snow, which persists for six months or more. The latitudinal extent of this basin results in the gradual snowmelting from south to north during spring/summer seasons and leads to large flood events. During the spring/summer season, the $\mathrm{Ob}$ ' River Basin is frequently described as the world's biggest swamp. The object of our study is the Lower Ob', the part of the $\mathrm{Ob}$ ' River comprised from the Yrtish mouth to the $\mathrm{Ob}$ ' bay (Fig. 1). The Lower Ob' is distinct from the Middle and the Upper $\mathrm{Ob}$ ' in terms of hydrological regime, permafrost conditions, and river management (i.e., dams and reservoirs). 


\subsection{The multisatellite inundation dataset}

The multisatellite inundation dataset quantifies at global scale the monthly distribution of surface water extent and its variations at $\sim 25 \mathrm{~km}$ of resolution. The methodology which captures the extent (with an accuracy of $\sim 10 \%$ ) of episodic and seasonal inundations, wetlands, rivers, lakes, and irrigated agriculture over more than a decade, 1993-2004, is based on a clustering analysis of a suite of complementary satellites observations, including passive (SSM/I) and active (ERS) microwaves, visible and near-IR (AVHRR) observations (Papa et al., 2007, 2008a,b, 2010; Prigent et al., 2007). As the microwave measurements are also sensitive to snow cover, snow masks are used to edit the results and avoid any confusion with snow-covered pixels. The weekly North Hemisphere and South Hemisphere snow mask from the National Snow and Ice Data Center (University of Colorado; NSIDC) is adopted and averaged on a monthly basis (Armstrong and Brodzik, 2005).

This dataset has been intensively used for climatological and hydrological analyses, such as the evaluation of the methane surface emission models (Ringeval et al., 2010) or the validation of the river flooding scheme in land surface models (Decharme et al., 2008). In high latitudes regions, Papa et al. (2007) evaluated the consistency of the spatial and temporal variations of this inundation dataset over the $\mathrm{Ob}$ ' basin using in situ snow depth and river runoff, and Papa et al. (2008) investigated the response of river discharge to seasonal flood extent change in the large Siberian watersheds.

\section{$2.3 \quad$ T/P-derived water levels}

First devoted to ocean studies, radar altimetry is now commonly used to monitor water levels over lakes, rivers and floodplains (Calmant et al., 2008). In this study, we built an altimetry-based hydrological network of 90 (old orbit: 19932002) and 92 (new orbit: 2002-2005) time series of water levels derived from T/P measurements over the Lower $\mathrm{Ob}$ ' drainage basin (see Fig. 1 for their locations), following the methodology previously proposed by Frappart et al. (2006a), for the period 1993-2004. All relevant environmental and geophysical corrections of the altimeter range measurements were applied. They include ionospheric, dry and wet tropospheric, solid Earth tide and pole tide corrections and correction for the satellite's centre of gravity. Following Kouraev et al. (2005), corrections specific to open ocean environments such as ocean tides, ocean tide loading, inverted barometer effect and sea state bias were neglected. For each intersection between the river (or the floodplain) and the satellite ground track, we define a so-called "altimetry station", represented by a rectangular window. Outliers are deleted using a 3- $\sigma$ criterion over the whole time span of analysis. For each 10 day cycle, the water level at a given altimetry station is obtained by computing the median of all the high-rate data $(10 \mathrm{~Hz})$ included in the rectangular window. This process, repeated for each cycle, allows the construction of a water level time-series at the altimetry station. All the water levels are expressed with respect to the static GGM02C geoid model (Tapley et al., 2005). The uncertainty associated with the water level height ranges between $5-25 \mathrm{~cm}$ for high water season to $15-50 \mathrm{~cm}$ during low water season. Note that in high latitudes regions, the presence of ice and snow perturbs the altimetric signal during a large portion of the year (Kouraev et al., 2005).

\subsection{GRACE - derived land water and snow mass solutions}

The Gravity Recovery And Climate Experiment (GRACE) mission, launched in March 2002, provides measurements of the spatio-temporal changes in Earth's gravity field. Several recent studies have shown that GRACE data over the continents can be used to derive the monthly changes of the total land water storage (Ramillien et al., 2005, 2008; Schmitt et al., 2008) with an accuracy of $\sim 1.5 \mathrm{~cm}$ of water equivalent thickness when averaged over regions of a few hundreds square-kilometres. The Level-2 GRACE solutions consist of monthly estimates of geo-potential coefficients adjusted for each 30-day period from raw along-track GRACE measurements by different research groups (i.e., CSR, GFZ and JPL). These coefficients are developed up to a degree 60 (or spatial resolution of $333 \mathrm{~km}$ ) and corrected for oceanic and atmospheric effects (Bettadpur, 2007) to obtain residual global grids of ocean and land signals corrupted by a strong noise. These data are available at: ftp://podaac.jpl.nasa.gov/grace/. Here we used the three latest land water solutions (RL04) produced by GFZ, JPL (for these two first products, January 2003, June 2003 and January 2004 are missing), and CSR (June 2003 and January 2004 are missing) and the derived snow solutions (Frappart et al., 2006b, 2010).

\subsection{Water in the root zone from hydrological models}

\subsubsection{The LaD model}

The LaD model provides monthly $1^{\circ} \times 1^{\circ}$ gridded time series of surface parameters. For each cell of the model, the total water storage is composed of three stores: a snowpack store, a root-zone store and a groundwater store and the total energy storage is equal to the sum of latent heat of fusion of the snowpack and the glacier and sensible heat content (Milly and Schmakin, 2002). Unfortunately, it contains no representation of the permafrost.

\subsubsection{The WGHM model}

The Water GAP Global Hydrology Model (WGHM) was specifically designed to estimate river discharge for water resources assessments. It computes $0.5^{\circ} \times 0.5^{\circ}$ gridded time series of monthly runoff and river discharge and is tuned against time series of annual river discharges measured 
at 724 globally distributed stations. The soil water balance takes into account the water content of the soil within the effective root zone, the effective precipitation as the sum of throughfall and snowmelt, the actual evapotranspiration and the surface runoff. Surface runoff is computed from the water balance equation that takes the water content within the effective root zone, the effective precipitation and the evapotranspiration into account (Döll et al., 2003). This model employs a minimization function including a permafrost/glacier-related factor for the recharge of the aquifer described in Döll and Fiedler (2008).

We use the water content within the root zone from these two models to simulate the soil moisture reservoir. It is important to note that WGHM takes into account the occurrence of permafrost in a grid cell for the groundwater recharge but $\mathrm{LaD}$ does not, and to keep in mind that these two models are unable to reproduce the complex mechanisms that occurred in the permafrost, active-layer, and talik, as described, for instance, in MacKay (1995).

\subsection{Precipitation estimates from GPCP}

These data quantify the distribution of precipitation over the global land surface (Adler et al., 2003). We use the monthly Satellite-Gauge Combined Precipitation Data product Version 2 data, available from January 1997 to present with a spatial resolution of $1^{\circ}$ of latitude and longitude. Over land surfaces, the uncertainty in the rate estimates from GPCP is generally lower than over the oceans due to the in situ gauge input (in addition to satellite) from the GPCC (Global Precipitation Climatology Center). Over land, validation experiments have been conducted in a variety of location worldwide and suggest that while there are known problems in regions of persistent convective precipitation, non precipitating cirrus or regions of complex terrain, the estimates uncertainties range between 10\%-30\% (Adler et al., 2003).

\subsection{In situ hydrological data from ArcticRIMS}

Daily water levels from the Salekhard station between February 2000 and December 2004, and monthly river discharges from Salekhard station between January 1993 and December 2004, and Belogorje station (see Fig. 1 for the location of these two stations) between January 1993 and October 1999 (but with missing data over long time periods for Belogorje station) were obtained from the ArcticRIMS web site (ArcticRIMS, 2003).

\section{Methodology}

\subsection{Monthly maps of water levels}

Monthly maps of water levels over the floodplains of the Lower $\mathrm{Ob}$ ' Basin have been determined using combined observations from the multi-satellite inundation dataset and the
T/P derived water levels at the altimetry stations. For a given month during the flood season, water levels were linearly interpolated over the flooded zones of the Lower Ob' Basin. A pixel of $25 \mathrm{~km} \times 25 \mathrm{~km}$ is considered inundated when its percentage of inundated area is greater than 0 . Maps of interpolated surface water levels with $25 \mathrm{~km}$ resolution have been constructed for each month between January 1993 and December 2004. The elevation of each pixel of the water level maps is given with reference to its minimum computed over the 1993-2004 period. This minimum elevation represents either the bathymetry or very low water stage of the floodplain. More details about the methodology can be found in Frappart et al. (2005, 2006c, 2008).

\subsection{Rescaling of the GRACE data}

The GRACE solutions suffer from the presence of important high-frequency noise (i.e., north-south striping) caused by orbit resonance in spherical harmonics determination and aliasing of short-time phenomena which are geophysically unrealistic. An optimum filter method was determined by analyzing the correspondance of GRACE basin-average water storage to the ensemble mean of hydrological models (WGHM, LaD) and by analyzing the error budgets (satellite/leakage errors) and amplitude and phase biases for the diffferent filter types. For the Lower Ob' Basin, the simple Gaussian filter with $500 \mathrm{~km}$ radius was the best filter. Only a very small bias in the seasonal phase of storage changes resulted due to filtering for the selected optimum filter methods. The GRACE products have been rescaled with a factor of 0.98 to account for amplitude smoothing due to filtering determined from smoothed and unsmoothed basin-average model ensemble time series of water storage (Werth et al., 2009).

\subsection{Total soil and groundwater storages estimates}

The time variations in Terrestrial Water Storage (TWS) are the sum of the contributions of the different reservoirs present in a drainage basin:

$$
\Delta \mathrm{TWS}=\Delta \mathrm{SW}+\Delta \mathrm{SN}+\Delta \mathrm{TSS}
$$

with $\Delta \mathrm{TSS}=\Delta \mathrm{RZ}+\Delta \mathrm{GW}+\Delta \mathrm{P}$

where SW represents the total surface water storage including lakes, reservoirs, in-channel and floodplains water, SN is the snow storage, TSS is the total soil storage including RZ the water contained in the root zone of the soil (representing a depth of 1 or $2 \mathrm{~m}$ ), GW the groundwater storage in the aquifers, and $\mathrm{P}$ the permafrost storage. These terms are generally expressed in volume $\left(\mathrm{km}^{3}\right)$ or $\mathrm{mm}$ of equivalent-water height.

The sum of GW and P anomalies over 2003-2004 is obtained in Eq. (1) by calculating the difference between the TWS anomaly estimated by GRACE and the SW level 
anomaly maps previously derived from remote sensing and the RZ anomaly derived from hydrological models outputs. The TWS and RZ monthly anomalies are the average anomalies of respectively the Level-2 GRACE CSR, GFZ and JPL destriped and smoothed solutions at $300 \mathrm{~km}$ of averaging radius, and the outputs from $\mathrm{LaD}$ and WGHM.

\subsection{Water volume variations}

For a given month $t$, the regional water volume of TWS, SW, TSS, SN, RZ or GW + P storage $\delta V(t)$ in a basin with surface area $S$, is simply computed from the water heights $\delta h_{j}$, with $j=1,2, \ldots$ (expressed in $\mathrm{mm}$ of equivalent water height) inside $S$, and the elementary surface $R_{\mathrm{e}}^{2} \sin \theta_{j} \delta \lambda \delta \theta$ (and the percentage of inundation $P_{j}$ for $\mathrm{SW}$ ):

$\delta V(t)=R_{\mathrm{e}}^{2} \sum_{j \in S} P_{j} \delta h_{j}\left(\theta_{j}, \lambda_{j}, t\right) \sin \theta_{j} \delta \lambda \delta \theta$

where $\lambda_{j}$ and $\theta_{j}$ are co-latitude and longitude respectively, $\delta \lambda$ and $\delta \theta$ are the grid steps in longitude and latitude (generally $\delta \lambda=\delta \theta$ ), and $R_{\mathrm{e}}$ the mean radius of the Earth $(\sim 6371 \mathrm{~km})$. The surface and total water volume variations are consequently expressed in $\mathrm{km}^{3}$.

\subsection{Annual cycle of water volumes}

From the series of TWS, SW, TSS, SN, RZ and GW + P anomaly grids, the temporal trend, seasonal and semi-annual amplitude were simultaneously fitted by least-square adjustment at each grid point. We assumed that, at 1st order, the changes $\delta q(t)$ at each grid point are the sum of a linear trend, an annual sinusoid (with frequency $\omega_{\mathrm{ann}}=\frac{2 \pi}{T_{\mathrm{ann}}}$, with $T_{\text {ann }} \sim 1$ year), a semi-annual sinusoid (with frequency $\omega_{\text {semi-ann }}=\frac{2 \pi}{T_{\text {semi-ann }}}$, with $T_{\text {semi-ann }} \sim 6$ months) and water mass residuals $\delta q^{\mathrm{RES}}(t)$ :

$$
\begin{aligned}
\delta q(t) & =A t+B+C \cos \left(\omega_{\text {ann }} t+\varphi_{\text {ann }}\right) \\
& +D \cos \left(\omega_{\text {semi }- \text { ann }} t+\varphi_{\text {semi-ann }}\right)+\delta q^{\mathrm{RES}}
\end{aligned}
$$

The parameters which we adjusted for each grid point $(\theta$, $\lambda$ ) are the linear trend (i.e. slope $A$ and y-intercept $B$ ), the annual cycle (i.e. amplitude $C$ and phase $\varphi_{\text {ann }}$ ) and the semiannual cycle (i.e. amplitude $D$ and phase $\varphi_{\text {semi-ann }}$ ). For this purpose, we merely used a error-free least-square fitting to solve the system:

$\delta Q=\Phi \cdot X$

where the vector $\delta Q$ is the list of the SWE values, $\boldsymbol{\Phi}$ and $\mathbf{X}$ are the configuration matrix and the parameter vector, respectively. The latter two terms are:

$$
\begin{aligned}
& \left\{\boldsymbol{\Phi}_{j}\right\}=\left[t_{j} 1 \cos \left(\omega_{\mathrm{ann}} t_{j}\right) \sin \left(\omega_{\mathrm{ann}} t_{j}\right)\right. \\
& \left.\cos \left(\omega_{\text {semi-ann }} t_{j}\right) \sin \left(\omega_{\text {semi-ann }} t_{j}\right)\right] \\
& \begin{aligned}
\mathbf{X}= & {\left[\alpha \beta \xi_{\text {ann }} \cos \varphi_{\text {ann }}-\xi_{\text {ann }} \sin \varphi_{\text {ann }} \xi_{\text {semi-ann }}\right.} \\
& \left.\cos \varphi_{\text {semi-ann }}-\xi_{\text {semi-ann }} \sin \varphi_{\text {semi-ann }}\right]
\end{aligned}
\end{aligned}
$$

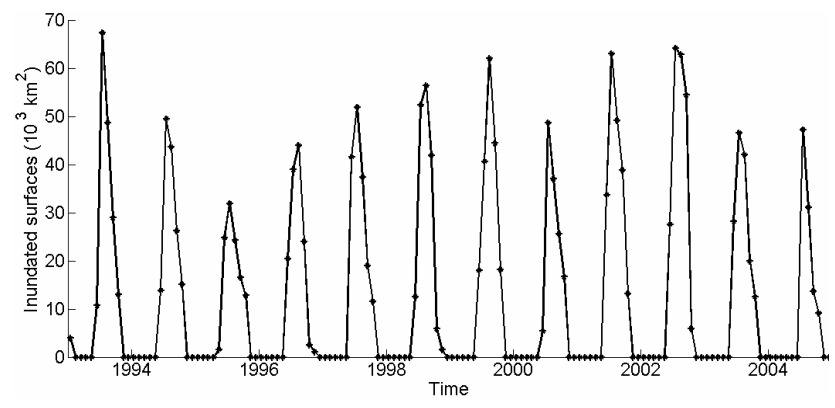

Fig. 2. Monthly time variations of the inundated areas $\left(\mathrm{km}^{2}\right)$ in the Lower Ob’ River Basin from 1993 to 2004.

for adjusting the temporal trend and for fitting the annual and semi-annual amplitude and phase.

According to the least-squares criteria, the solution vector of the linear system (Eq. 5) is:

$$
X^{\mathrm{SOL}}=\left(\Phi^{T} \Phi\right)^{-1} \Phi^{T} \delta Q
$$

\section{Results and discussion}

\subsection{Monthly inundation extent}

The inundated area fractions for the Lower $\mathrm{Ob}^{\prime}$ watershed were extracted from the multisatellite inundation dataset. The temporal evolution of the total inundated extent $\left(\mathrm{km}^{2}\right)$ over the lower Ob' River Basin for the period 1993-2004 is presented in Fig. 2. The mean extent during the snow-free months is only of $29 \times 10^{3} \mathrm{~km}^{2}$. The inundation extent always reaches its maximum in July, except for 1996, 1998, and 1999 where the maximum occurred in August. The inundation exhibits a strong seasonal cycle, with the floods generally starting in June and lasting until October. It also presents an important interannual variability. For example, in 1993, the maximum inundated extent reached $67 \times 10^{3} \mathrm{~km}^{2}$ whereas in 1995 , it only reached $32 \times 10^{3} \mathrm{~km}^{2}$.

The spatial pattern of the inundation over the Lower $\mathrm{Ob}^{\text {' }}$ Basin is shown in Fig. 3. Figure 3a displays maps of the annual maximum of fractional inundation extent (in \%, $100 \%$ of inundations equals to a total area of $773 \mathrm{~km}^{2}$ ) from satellite estimates for each year of the period 1993-2004. Figure $3 \mathrm{~b}$ shows the corresponding month during which the maximum inundation occurs. The inundation extent is clearly delineated over the river channel and the associated floodplains. The pixels with a very high percentage of inundation (greater than 50\%) are located along the river channel. A large inundation area is present downstream the junction between the $\mathrm{Ob}$ ' and the Irtysh Rivers around $60^{\circ} \mathrm{N}$ and $65^{\circ} \mathrm{E}$. 

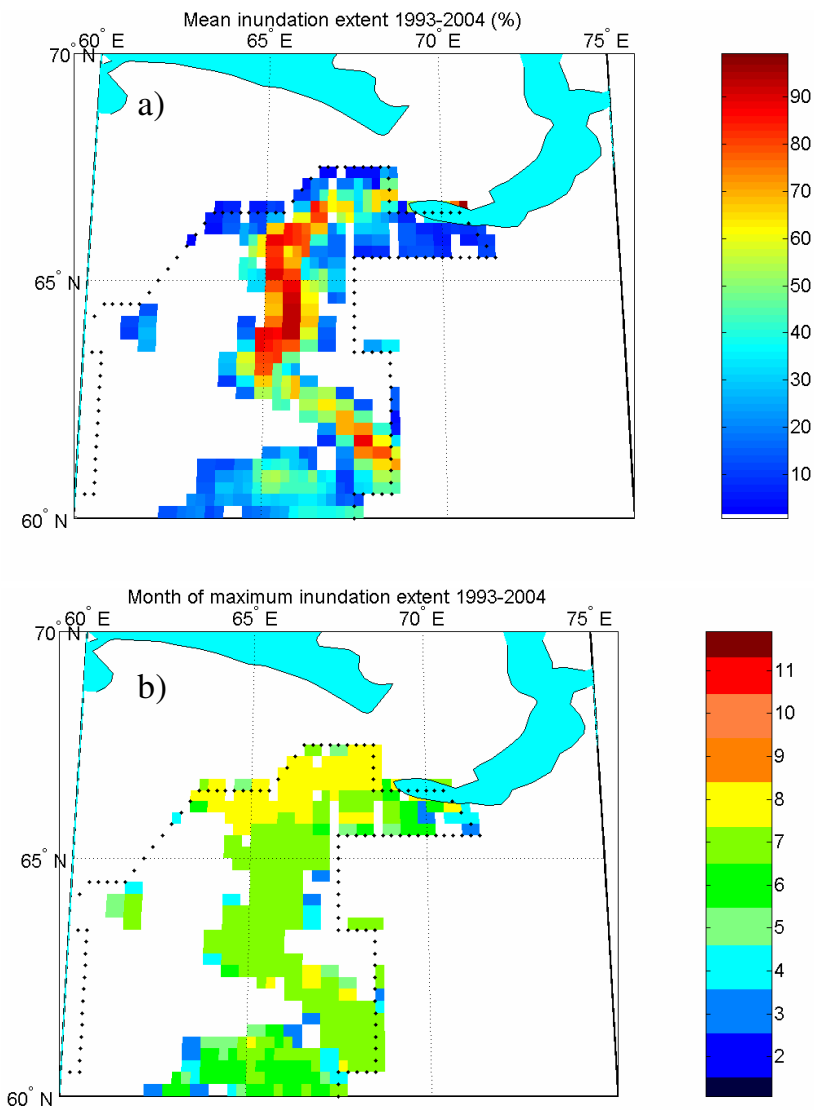

Fig. 3. (a) The 1993-2004 mean fractional inundation at yearly maximum (\%); (b) the average month of the year (1993-2004) when the fractional inundation is maximum (in month).

Figure $3 b$ presents a map of the month during which occurred the maximum inundation extent. As seen in the results from Papa et al. (2008), this map clearly shows a propagation from south to north resulting from the latitudinal dependence of the snow melting. The maximum inundation extent occurs from May to June in the southern part of the basin and from July to August on the northern region. The propagation of the maximum inundation extent from south to north generally takes two to three months (this rough estimate is limited by the monthly temporal resolution of the dataset).

\subsection{Altimetry-derived water levels time series}

The T/P altimetry stations where water level time series can be constructed are unevenly distributed across the basin (Fig. 1). An important point to notice is that this dataset gives valuable information on water levels especially for unmonitored regions of the Lower Ob' watershed, in particular over the floodplains.

The water level time series derived from radar altimetry for the stations close to Salekhard are presented in Fig. 4 along with in situ river heights time series. Comparisons have been

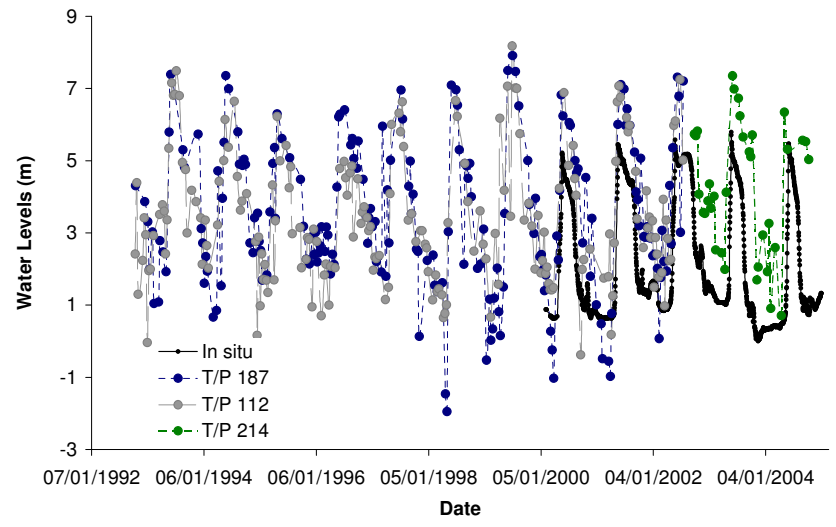

Fig. 4. Time series of water levels at Salekhard from in situ gauge (black), T/P altimetry stations.

Table 1. Comparisons between the gauge records from Salekhard and the water levels derived from T/P measurements.

\begin{tabular}{lcc}
\hline & RMS (m) & Correlation \\
\hline In situ/TP 112 (old orbit) & 0.89 & 0.89 \\
In situ/TP 187 (old orbit) & 1.32 & 0.84 \\
In situ/TP 214 (new orbit) & 1.34 & 0.69 \\
\hline
\end{tabular}

made between the in situ gauge station of Salekhard at the mouth of the Ob' River and the closest altimetry stations on the river channel for both the old and the new orbit of T/P (Table 1). For the old orbit, two altimetry stations can be defined at locations around $65 \mathrm{~km}$ at the South of Salekhard. As previously observed by Kouraev et al. (2004), a good agreement between altimetry-derived and in situ water levels is found with a correlation of 0.89 and a RMS of $0.89 \mathrm{~m}$ for T/P track 112 (old orbit). For the new orbit, the closest altimetry station is located around $100 \mathrm{~km}$ from Salekhard. As a consequence, the derived water levels do not agree as well as the ones from the old orbit with a correlation of 0.69 and a RMS of $1.34 \mathrm{~m}$.

\subsection{Monthly maps of water levels}

The monthly flood maps indicate that the flood period in the Lower $\mathrm{Ob}$ ' generally ranges from June to October, whereas low-water period ranges from December to April, during the winter with a maximum occurring generally in July due to the snowmelt. Figure 5 shows a series of maps of interpolated water levels over the floodplains at the maximum of inundation for the period 1993-2004. The maximum difference of water levels between high and low waters is lower than $6 \mathrm{~m}$ in the Lower Ob' Basin. Maximum differences of water levels between high and low stages are observed along the river stream. Large spatial and temporal variabilities are also revealed by the series of maps. 

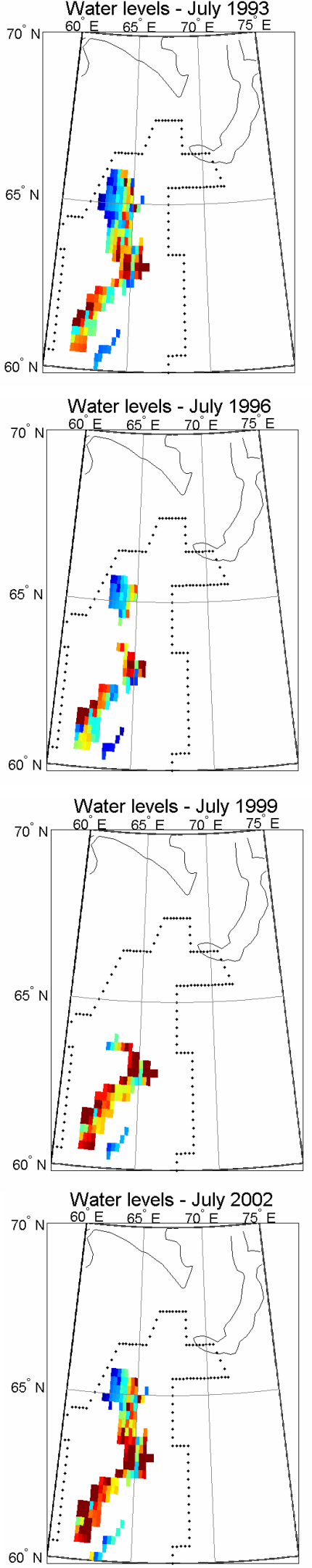
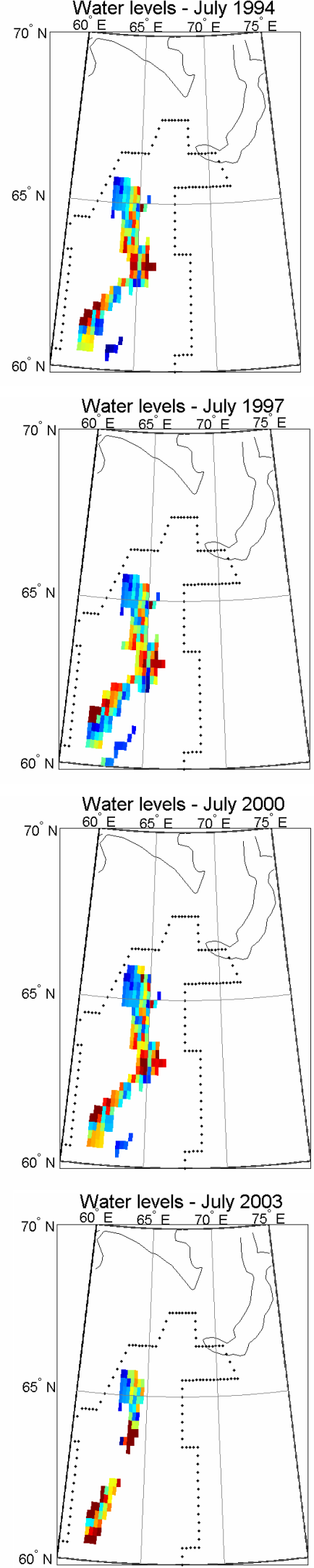
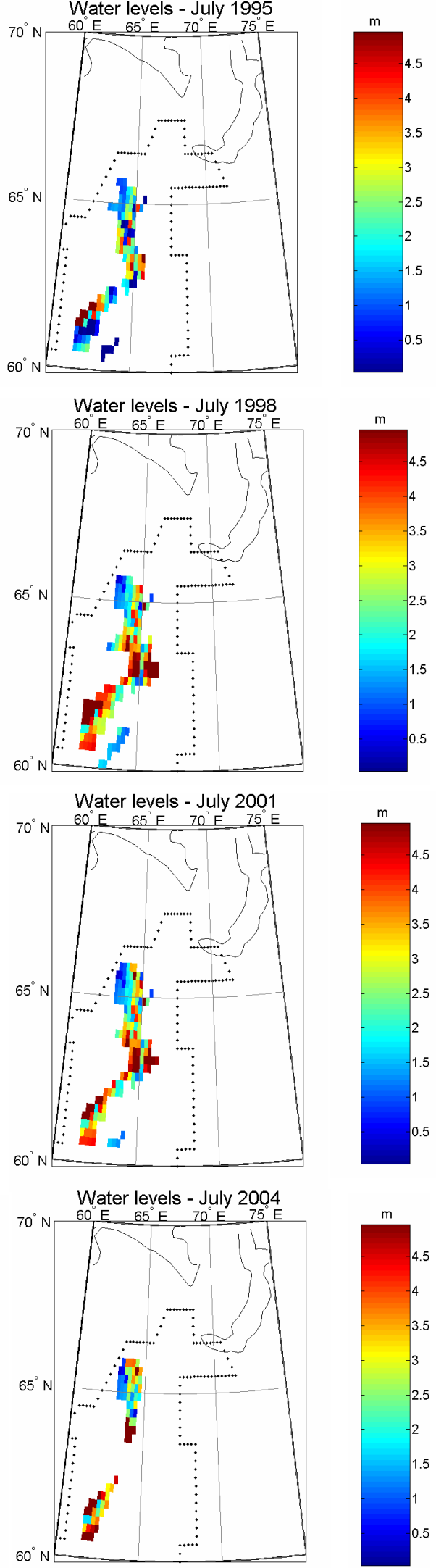

Fig. 5. Water level maps during the peak flood (July) for 1993-2004. 


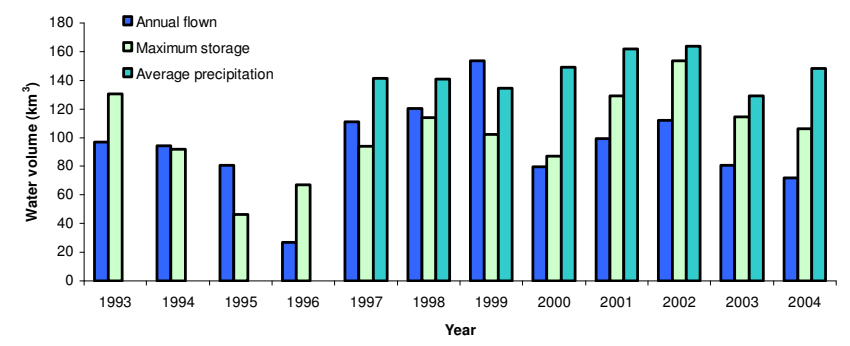

Fig. 6. Time series of annual maximum of surface water storage volume (light green), annual water volume flown in the Lower $\mathrm{Ob}$ ' Basin (blue), and annual water volume of precipitation.

The surface water interannual variability was compared with the one of river discharges and precipitation. The annual maximum surface water storage, i.e., the difference between the annual maximum and minimum surface water volumes, was confronted to the volume of water that has flown in the Lower Ob' Basin during the year, and to the annual amount of precipitation (expressed in terms of annual average) in the whole Ob' basin. The results are presented in Fig. 6.

The annual water volume flowed in the Lower Ob' watershed has been estimated by time-integrated the difference between the monthly river discharges in the outlet of the basin in Salekhard and the monthly river discharges corresponding to the contributions of the Upper and Middle $\mathrm{Ob}$ ', and of the Irtysh River in Belogorje. We completed the time series of monthly river discharges in Belogorje when data were missing multiplying the river discharges in Salekhard by 0.795 as observed by Yang et al. (2004) in its climatology of the Ob' River Basin.

Similar time variations can be observed between the annual water volume flown in the Lower Ob', as well as the maximum storage and the average precipitation.

\subsection{Water volume variations}

Using equations from Sects. 3.2 to 3.5 , the time series of volume of TWS and SN are presented along with the TSS in Fig. $7 \mathrm{a}$, the water contained in the root zone, and the sum of groundwater and permafrost in Fig. 7b over 2003-2004, i.e., the overlapping period of the different datasets.

These TWS and SN time series exhibit a comparable temporal evolution with maxima occurring during winter. The peak of surface water appears during the flood period, in spring/summer, with maximum in June. It is caused by both the local snowmelt and snowmelt from upstream locations (Papa et al., 2007), and large rainfall occurring between May and September. The time variations of the anomaly of TSS are mostly dominated by the groundwater and permafrost signals. The water stored in the root zone only represents a small fraction of the TWS, which is in good agreement with the presence of permafrost, and peaks when the snow starts melting in April or May. When the flood decreases, the
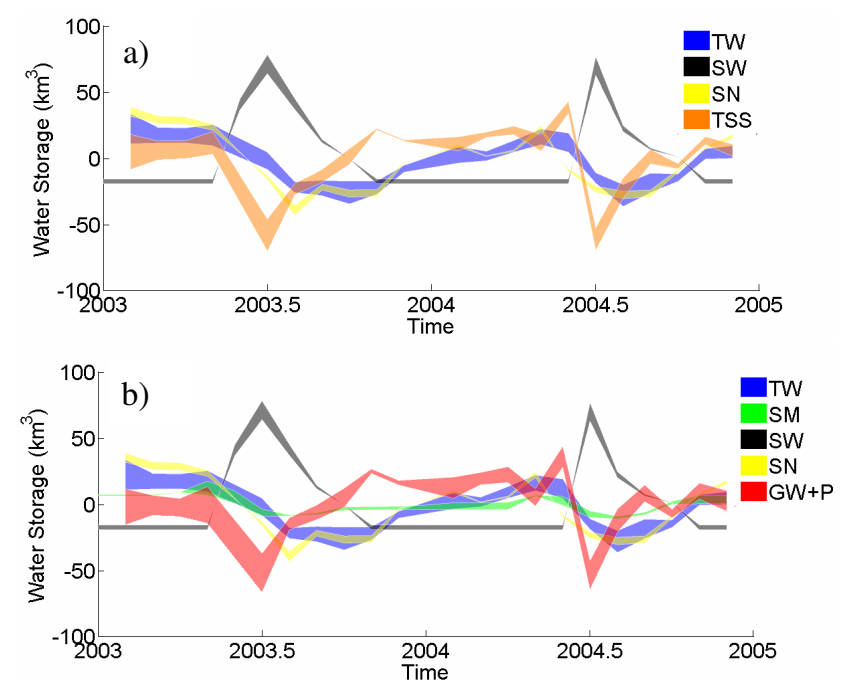

Fig. 7. (a) Monthly variations of TWS volume (blue), surface water volume from T/P radar altimetry and multisatellite inundation dataset (black), snow derived from GRACE measurements (yellow), TSS by difference between TWS and the other compartments (orange), monthly variations of TWS volume (blue), surface water volume from T/P radar altimetry and multisatellite inundation dataset (black), soil moisture from hydrological model outputs (green), snow derived from GRACE measurements (yellow), sum of groundwater and permafrost by difference between TWS and the other compartments (red). Units: $\mathrm{km}^{3}$.

recharge of the groundwater reservoir begins and lasts until mid-winter and the beginning of the snowmelt.

The spatial patterns of the TWS and of the different components of the land water cycle are presented in Figs. 8 and 9 in terms of amplitudes of the annual cycle over 2003-2004. The annual amplitude of TWS presents very low variations in the Lower Ob' Basin, from 50 in the South-East to $70 \mathrm{~mm}$ in the North-North West (Fig. 8a). The snow annual amplitude map presents a meridian gradient and largest amplitudes on the western part of the basin (up to $50 \mathrm{~mm}$, see Fig. 8b). Both spatial pattern and amplitudes are similar to climatologies (see Frappart et al., 2010), snow depth derived from microwave brightness temperatures and estimated by hydrological models (Biancamaria et al., 2010). TSS exhibits a strong North-South gradient, with larger variations in the eastern part of the basin, and following the permafrost distribution from Brown et al. (1998): high amplitudes around 30-35 mm in the South (especially in the South East) of the basin where the permafrost is isolated or sporadic to less than $15 \mathrm{~mm}$ in the North-East close to the mouth where the permafrost is discontinuous (Fig. 8c). RZ has a very low annual amplitude, except in the eastern part of the basin with value reaching $25 \mathrm{~mm}$ (Fig. 9a). The map of annual amplitude of the groundwater and permafrost components exhibits a low signal in the whole basin, except just below the junction between the Ob' and the Irtysh where it reaches $30 \mathrm{~mm}$ (Fig. 9b). The 


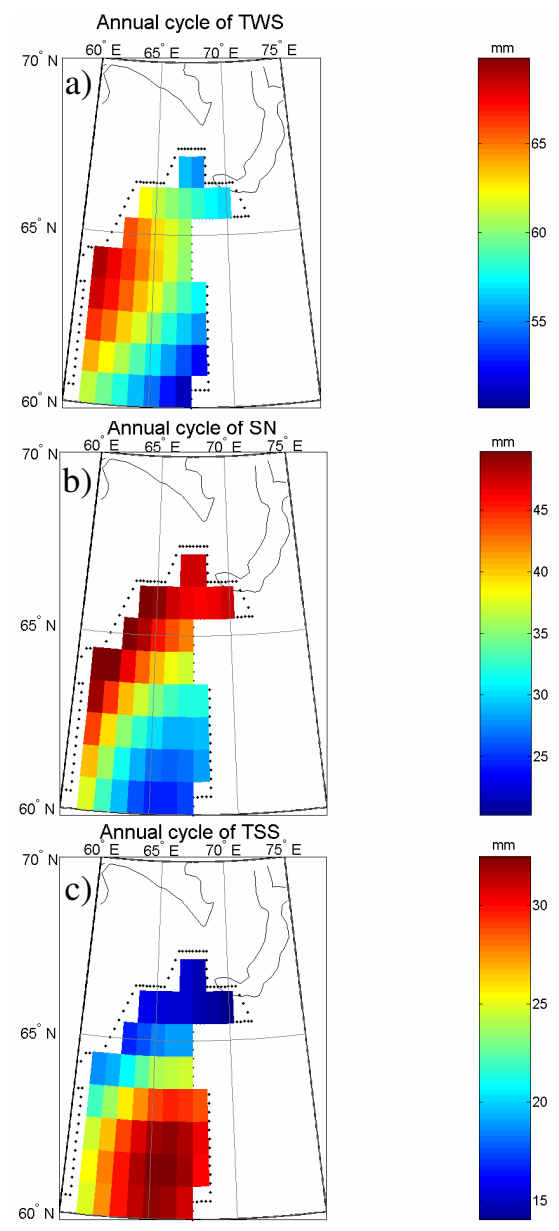

Fig. 8. Amplitude of the annual cycle over 2003-2004: (a) TWS from GRACE, (b) snow Water Equivalent (SWE) from GRACE, (c) total soil storage. Units: $\mathrm{mm}$.

recharge of the aquifer of the Lower Ob' Basin seems to be mainly related to the percolation of surface water in the large floodplains of the Lower $\mathrm{Ob}$ ' Basin rather than the melt of the snow present in the basin. The recharge process seems to be strongly related to the fluxes of water coming from the middle $\mathrm{Ob}$ ' and the Irtysh. Permafrost acts as a barrier to the groundwater recharge, increasing the surface runoff and diminishing the subsurface, low annual amplitudes of the annual cycle of RZ and GW + P are consistent with the presence of sporadic and discontinuous permafrost in the Lower $\mathrm{Ob}$ ' Basin. Nevertheless, this last result has to be considered with caution due to the lack of relevance of the hydrological models used in this study to permafrost, active-layer, and talik.
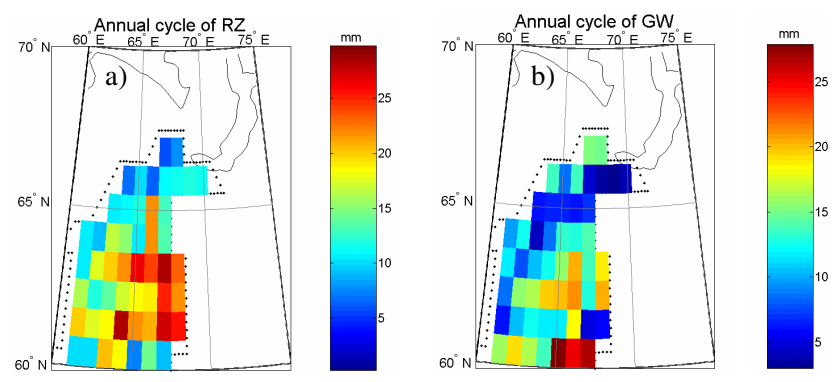

Fig. 9. Amplitude of the annual cycle over 2003-2004 of the components of the TSS: (a) water in the Root zone from hydrological models, (b) groundwater and permafrost. Units: $\mathrm{mm}$.

\section{Conclusions}

In this study, we estimated surface water extent and storage variations in the Lower Ob' for the 1993-2004 period. The combined use of altimetric water level observations from $\mathrm{T} / \mathrm{P}$ and inundation patterns derived from multisatellite information to determine water volume variations provides valuable information on the inundation dynamics of river floodplains in the Arctic drainage basins. These surface water volume variations exhibit similar interannual variations as water flowed in the Lower Ob' Basin and precipitation. Seasonal and interannual variabilities are consistent with precipitation and river discharges. Monitoring the variability of both flood extent and storage is crucial to better understand the relationships between snow, flood and surface runoff. These results are also of great interest for the preparation of the future wide swath altimetry mission SWOT (Surface Water and Ocean Topography) that will measure 2-D water levels over a $120 \mathrm{~km}$ swath.

The complementarity between remote sensing derived hydrological products (altimetry, imagery and gravimetry from space) allowed us to estimate the time variations of TSS. Adding information from hydrological modelling, we were able to determine the time variations of the water stored in the aquifers and the permafrost of the Lower Ob' watershed over 2003-2004. We observed that most of the TSS time variations are due to the groundwater and permafrost. It is important to keep in mind that soil storage from the hydrological models are likely to be erroneous due the inaccurate (WGHM) or lack (LaD) of modelling the permafrost, active-layer, and talik. These results have important implications for the better understanding of the pan-Arctic hydrology, and especially the possible role of the groundwater in the increase in river discharge to the Arctic Ocean (Smith et al., 2007; Ye et al., 2009). Further work has to be done to investigate the possible increase of subsurface storage in the watersheds covered with permafrost by extending the common availability of these datasets to a longer time-period. 
Acknowledgements. This work was partly supported by the foundation STAE in the framework of the CYMENT project and by NASA's NEWS Grant NNDX7AO90E managed by Jared K. Entin. The authors would like to thank the Centre de Topographie des Océans et de l'Hydrosphère $(\mathrm{CTOH})$ at Laboratoire d'Etudes en Géophysique et Océanographie Spatiales (LEGOS), Observatoire Midi-Pyrénées (OMP), Toulouse, France, for the provision of the Topex/Poseidon GDR dataset. They also wish to thank two anonymous referees for their constructive remarks.

Edited by: W. Wagner

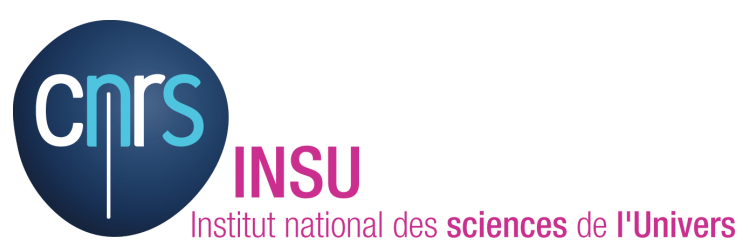

The publication of this article is financed by CNRS-INSU.

\section{References}

Adler, R. F., Huffman, G. J., Chang, A., Ferraro, R., Xie, P., Janowiak, J., Rudolf, B., Schneider, U., Curtis, S., Bolvin, D., Gruber, A., Susskind, J., and Arkin, P.: The Version 2 Global Precipitation Climatology Project (GPCP) monthly precipitation analysis (1979-present), J. Hydrometeorol., 4, 1147-1167, doi:10.1175/1525-7541(2003)004<1147:TVGPCP > 2.0.CO;2, 2003.

ArcticRIMS: A Regional, Integrated Hydrological Monitoring System for the Pan-Arctic Land Mass, http://www.watsys.sr.unh. edu/arctic/RIMS/, last access: October 2009, 2003.

Armstrong, R. L. and Brodzik, M. J.: Northern Hemisphere EASE-Grid weekly snow cover and sea ice extent version 3, National Snow and Ice Data Center, Digital media, see urlhttp://nsidc.org/data/nsidc-0046.html, last access: October 2009, Boulder, Colorado USA, 2005.

Bettadpur, S.: CSR level-2 processing standards document for level-2 product release 0004, GRACE 327-742, Rev. 3.1, 18 pp., 2007.

Biancamaria, S., Cazenave, A., Mognard, N. M., Llovel, W., and Frappart, F.: Satellite-based high latitude snow volume trend and, variability, and contribution to sea levelover 1989-2006, Global Planet. Change, accepted, doi:10.1016/j.gloplacha.2010.10.011, 2010.

Brown, J., Ferrians Jr., O. J., Heginbottom, J. A., and Melnikov, E. S.: Circum-Arctic map of the permafrost and ground ice conditions, National Snow and Ice Data Center/World Data Center for Glaciology, see http://nsidc.org/data/ggd318.html, last access: November 2010, Digital Media, Boulder, CO, 1998, revised, February, 2001.

Bullock, A. and Acreman, M.: The role of wetlands in the hydrological cycle, Hydrol. Earth Syst. Sci., 7, 358-389, doi:10.5194/hess-7-358-2003, 2003.

Calmant, S., Seyler, F., and Crétaux, J.-F.: Monitoring continental surface waters by satellite altimetry, Surv. Geophys., 29, 247269, doi:10.1007/s10712-008-9051-1, 2008. de Marsily, G.: Eaux continentales, C. R. Geosci., 337, 1-2, 2005. Decharme, B., Douville, H., Prigent, C., Papa, F., and Aires, F.: A new river flooding scheme for global climate applications: Off-line validation over South America, J. Geophys. Res., 113, D11110, doi:10.1029/2007JD009376, 2008.

Döll, P. and Fiedler, K.: Global-scale modeling of groundwater recharge, Hydrol. Earth Syst. Sci., 12, 863-885, doi:10.5194/hess-12-863-2008, 2008.

Döll, P., Kaspar, F., and Lehner, B.: A global hydrological model for deriving water availability indicators: Model tuning and validation, J. Hydrol., 270, 105-134, 2003.

Frappart, F., Martinez, J.-M., Seyler, F., León, J. G., and Cazenave, A.: Floodplain water storage in the Negro River basin estimated from microwave remote sensing of inundation area and water levels, Remote Sens. Environ., 99, 387-399, doi:10.1016/j.rse.2005.08.016, 2005.

Frappart, F., Calmant, S., Cauhopé, M., Seyler, F., and Cazenave, A.: Preliminary results of ENVISAT RA-2 derived water levels validation over the Amazon basin, Remote Sens. Environ., 100, 252-264, doi:10.1016/j.rse.2005.10.027, 2006a.

Frappart, F., Ramillien, G., Biancamaria, S., Mognard, N. M., and Cazenave, A.: Evolution of high-latitude snow mass derived from the GRACE gravimetry mission (2002-2004), Geophys. Res. Lett., 33, L02501, doi:10.1029/2005GL024778, 2006 b.

Frappart, F., Do Minh, K., L'Hermitte, J., Cazenave, A., Ramillien, G., LeToan, T., and Mognard-Campbell, N.: Water volume change in the lower Mekong basin from satellite altimetry and imagery data, Geophys. J. Int., 167(2), 570-584, doi:10.1111/j.1365-246X.2006.03184.x, 2006c.

Frappart, F., Papa, F., Famiglietti, J. S., Prigent, C., Rossow, W. B., and Seyler, F.: Interannual variations of river water storage from a multiple satellite approach: a case study for the Rio Negro River basin, J. Geophys. Res., 113, D21104, doi:10.1029/2007JD009438, 2008.

Frappart, F., Ramillien, G., and Famiglietti, J. S.: Water balance of the Arctic drainage system using GRACE gravimetry products, Int. J. Remote Sens., in press, doi:10.1080/01431160903474954, 2010.

Grippa, M., Mognard, N. M., and Le Toan, T.: Comparison between the interannual variability of snow parameters derived from SSM/I and the Ob river discharge, Remote Sens. Environ., 98, 35-44, 2005.

Hall, D. K., Kelly, R. E. J., Riggs, G. A., Chang, A. T. C., and Foster, J. L.: Assessment of the relative accuracy of hemispheric-scale snow-cover maps, Ann. Glaciol., 34(1), 24-30, 2002.

Kane, D. L.: The impact of Arctic hydrologic perturbations on Arctic ecosystems induced by climate change, in Global Change and Arctic Terrestrial Ecosystems, Ecol. Stud., edited by: Oerchel, W. C., Callaghan, T., Gilmanov, T., Holten, J. I., Maxwell, B., Molau, U., and Sveinbjörnsson, B., Springer, New York, 124, 63-81, 1997.

Kouraev, A. V., Zakharova, E. A., Samain, O., Mognard, N. M., and Cazenave, A.: Ob' River discharge from Topex-Poseidon satellite altimetry (1992-2002), Remote Sens. Environ., 93, 238245, 2004.

Leblanc, M. J., Tregoning, P., Ramillien, G., Tweed, S. O., and Fakes, A.: Basin-scale, integrated observations of the early 21 st century multiyear drought in southeast Australia, Water Resour. Res., 45, W04408, doi:10.1029/2008WR007333, 2009. 
MacKay, J. R.: Active Layer Changes (1968 to 1993) following the Forest-Tundra Fire, Inuvik, N. W. T., Canada, Arctic Alpine Res., 27(3), 323-336, 1995.

Maltby, E.: Wetland management goals: Wise use and conservation, Landscape Urban Plan., 20, 9-18, 1991.

Massom, R: Satellite remote sensing of polar snow and ice: present status and future directions, Polar Res., 31(1), 99-114, 1995.

Milly, P. C. D. and Shmakin, A. B.: Global modeling of land water and energy balances: 1 . The Land Dynamics (LaD) model, J. Hydrometeorol., 3, 283-299, 2002.

Muskett, R. R. and Romanovsky, V. E.: Groundwater storage changes in arctic permafrost watersheds from GRACE and in situ measurements, Environ. Res. Lett., 4(3), 045009, 2009.

Organisation for Economic Cooperation and Development: Guidelines for Aid Agencies for Improved Conservation and Sustainable Use of Tropical and Sub-tropical Wetlands, Guidelines Aid Environ., 9, Paris, France, 69 pp., 1996.

Papa, F., Prigent, C., and Rossow, W. B.: Ob' River flood inundations from satellite observations: a relationship with winter snow parameters and river runoff, J. Geophys. Res., 112, D18103, doi:10.1029/2007JD008451, 2007.

Papa, F., Prigent, C., and Rossow, W. B.: Monitoring Flood and Discharge Variations in the Large Siberian Rivers From a MultiSatellite Technique, Surv. Geophys., 29, 297-317, 2008a.

Papa, F., Güntner, A., Frappart, F., Prigent, C., and Rossow, W. B.: Variations of surface water extent and water storage in large river basins: A comparison of different global data sources, Geophys. Res. Lett., 35, L11401, doi:10.1029/2008GL033857, 2008b.

Papa, F., Prigent, C., Aires, F., Jimenez, C., Rossow, W. B., and Matthews, E.: Interannual variability of surface water extent at global scale, J. Geophys. Res., 115, D12111, doi:10.1029/2009JD012674, 2010.

Peterson, B. J., Holmes, R. M., McClelland, J. W., Vörösmarty, C. J., Lammers, R. B., and Shiklomanov, A. I.: Increasing river discharge to the Artic Ocean, Science, 298, 2171-2173, 2002.

Prigent, C., Papa, F., Aires, F., Rossow, W. B., and Matthews, E.: Global inundation dynamics inferred from multiple satellite observations, 1993-2000, J. Geophys. Res., 112, D12107, doi:10.1029/2006JD007847, 2007.

Ramillien, G., Frappart, F., Cazenave, A., and Güntner, A.: Time variations of the land water storage from an inversion of 2 years of GRACE geoids, Earth Planet. Sc. Lett., 235, 283-301, doi:10.1016/j.eps1.2005.04.005, 2005.

Ramillien, G., Famiglietti, J. S., and Wahr, J.: Detection of continental hydrology and glaciology signals from GRACE: A review, Surv. Geophys., 29(4-5), 361-374, doi:10.1007/s10712008-9048-9, 2008.

Ringeval, B., de Noblet-Ducoudré, N., Ciais, P., Bousquet, P., Prigent, C., Papa, F., and Rossow, W. B.: An attempt to quantify the impact of changes in wetland extent on methane emissions on the seasonal and interannual time scales, Global Biogeochem. Cy., 24, GB2003, doi:10.1029/2008GB003354, 2010.

Robinson, D. A. and Frei, A.: Seasonal variability of northern hemisphere snow extent using visible data, Prof. Geogr., 52(2), 307$315,2000$.

Roddel, M., Velicogna, I., and Famiglietti, J. S.: Satellite-based estimates of groundwater depletion in India, Nature, 460, 9991003, doi:10.1038/nature08238, 2009.
Schmidt, R., Flechtner, F., Meyer, U., Neumayer, K.-H., Dahle, Ch., Koenig, R., and Kusche, J.: Hydrological Signals Observed by the GRACE Satellites, Surv. Geophys., 29, 319-334, doi:10.1007/s10712-008-9033-3, 2008.

Seidel, K. and Martinec, J.: Remote sensing in snow hydrology: runoff modelling, effect of climate change, Springer Praxis books - Geophysical Sciences, Berlin, 150 pp., 2004.

Serreze, M. C., Walsh, J. E., Chapin III, F. S., Osterkamp, T., Dyurgerov, M., Romanovsky, V., Oechel, W. C., Morison, J., Zhang, T., and Barry, R. G.: Observational evidence of recent change in the northern high-latitude environment, Climatic Change, 46, 159207, 2000.

Shiklomanov, I. A., Lammers, R. B., Peterson, B. J., and Vörösmarty, C. J.: The dynamics of river water inflow to the Arctic Ocean. In the freshwater budget of the Arctic Ocean, proc. of the NATO advanced research workshop, Kluwer Academic Publishers, Norwell, 281-296, 2000.

Smith, L. C.: Satellite remote sensing of river inundation area, stage and processes: a review, Hydrol. Process., 11, 1427-1439, 1997.

Smith, L. C., Sheng, Y., MacDonald, G. M., and Hinzman, L. D.: Disapearing Arctic lakes, Science, 308, 1429, doi:10.1126/science.1108142, 2005.

Smith, L. C., Pavelsky, T. M., MacDonald, G. M., Shiklomanov, A. I., and Lammers, R. B.: Rising minimum daily flows in northern Eurasian rivers: a growing influence of groundwater in the high-latitude hydrologic cycle, J. Geophys. Res., 112, G04S47, doi:10.1029/2006JG000327, 2007.

Stocker, T. F. and Raible, C. C.: Water cycle shifts gear, Nature, 434, 1560-1563, 2005.

Tapley, B., Ries, J., Bettadpur, S., Chambers, D., Cheng, M., Condi, F., Gunter, B., Kang, Z., Nagel, P., Pastor, R., Pekker, T., Poole, S., and Wang, F.: GGM02 - an improved Earth gravity field model from GRACE, J. Geodesy, 79, 467-478, doi:10.1007/s00190-005-0480-z, 2005.

Werth, S., Güntner, A., Schmidt, R., and Kusche, J.: Evaluation of GRACE filter tools from a hydrological perspective, Geophys. J. Int., 179, 1499-1515, doi:10.1111/j.1365-246X.2009.04355.x, 2009.

Woo, M.-K.: Permafrost hydrology in North America, Atmos. Ocean, 24(2), 201-234, 1986.

Wu, P., Wood, R., and Stott, P.: Human influence on increasing Arctic river discharges, Geophys. Res. Lett., 32, L02703, doi:10.1029/2004GL0215, 2005.

Yang, D., Kane, D. L., Hinzman, L. D., Zhang, X., Zhang, T., and Ye, H.: Siberian Lena river hydrologic regime and recent change, J. Geophys. Res., 107(D23), 4694, 2002.

Yang, D., Ye, B., and Shiklomanov, A.: Discharge characteristics and changes over the Ob' River watershed in Siberia, J. Hydrometeorol., 5, 595-610, 2004.

Ye, B., Yang, D., Zhang, Z., and Kane, D. L.: Variation of hydrological regime with permafrost coverage over Lena basin in Siberia, J. Geophys. Res., 114, D07102, doi:10.1029/2008JD010537, 2009.

Zhang, T., Barry, R. G., Knowles, K., Heginbottom, J. A., and Brown, J.: Statistics and characteristics of permafrost and ground-ice distribution in the Northern Hemisphere, Polar Geogr., 23(2), 132-154, 1999. 